\title{
Ecological Assessment of Hooghly - Bhagirathi River System through the Study of Diversity of Bivalves and Gastropods in Relation to Physico-Chemical Parameters
}

\author{
Bhuban Mohan Majhi', Ashim Kumar Nath ${ }^{2 *}$, Chiranjeeb Dey ${ }^{1}$, \\ Ayan Mondal ${ }^{3}$ and Nimai Chandra Saha ${ }^{4}$
}
${ }^{1}$ Department of Zoology, Serampore College, Serampore, Hooghly, West Bengal, India
${ }^{2}$ Department of Zoology, Sidho-Kanho-Birsha University, Purulia, West Bengal, India
${ }^{3}$ Department of Environmental Science, University of Burdwan, West Bengal, India
${ }^{4}$ Vice Chancellor, University of Burdwan, West Bengal, India

*Corresponding author

\section{A B S T R A C T}

Ke y w o r d s
Gastropod, Bivalve,
Physico-chemical
parameters,
Principle
component analysis,
General linear
model

\section{Introduction}

In the world, fresh water ecosystem is being subjected to unexpected level of anthropogenic disturbance (Loh et al., 1998). In the developing countries pollution of surface water as well as ground water is a major problem (Yan et al., 2015). For
It is generally considered that benthic organisms are good indicator of environmental condition of aquatic ecosystem. Present study focused on seasonal distribution of macrobenthic fauna and physico-chemical parameters of Hooghly-Bhagirathi river (part of Ganga river) during one year from June 2016 to May 2017. Total 16 species of mollusks (11 species of gastropods belonging to seven families and 4 species of bivalves belonging to the three families) have been found during study period. Among them Tarebia lineata, Filopaludina bengalensis, Novaculina gangetica and Lamellidens marginalis are found to be the most dominant species of the studied region of Ganga river. Four stations had been selected for the purpose of study (Station 1: Nabadwip, Station 2: Mayapur, Station 3: Khardaha, Station 4: Raichak) along the entire stretch of studied river. Gastropod and bivalves represent $43.59 \%$ and $56.41 \%$ of the total molluscs respectively. Principle component analysis (PCA) was done to determine the relationship among molluscan fauna and physico chemical variables of water. General linear model (GLM) was also done which gives a satisfactory result. Rarefraction curves confirmed the low probability of finding of addition of new species in station-1, whereas the probability of finding new species in case of station-2, station-3, station-4 are very low. 
2001). Studies on benthic organism in natural water are of fundamental importance as they form the basic food for many fish species and invertebrate bottom dwellers of economic significance. Benthos have been employed to assess the past and present environmental condition of an ecosystem more efficiently than physical and chemical indices of water and soil (Hofmann, 1978) and are sedentary, sessile, long lived and easily collectable (Petersen,1913). Hence it is prudent to study the relationship between organism and environment. Molluscs are second largest phylum after arthropod (Ellen et al., 2008). Gastropods and Bivalves are the two major classes of this Phylum. Some molluscs are epifauna (living on mud or surface area of the land), some are infauna (burying themselves in the mud) and some are arboreal (attached to stem and roots of the vegetation and some are with overlapping habitat (Dey, 2006-2009; Kesavan et al., 2009).

Molluscs play many vital roles in maintaining the ecosystem. They can degrade the organic detritus as they take living and decaying algae and plant material (Shanmugan and Vairmani, 2009; Kelaher et al., 2007). Grazing gastropods are very efficient to control macro algal bloom and different epiphytes (Pace et al., 1979; Geller, 1991; Hily et al., 2004; Jenkins and Hartnoll, 2001). In the food web they place themselves in possible all the levels like predator, herbivores, detritus and filter feeder (Boodninathan et al., 2012). Freshwater mussel (Class: Bivalvia, Family: Unionidae) play vital role by filtering and removing phytoplankton and other suspended particulate matter from the aquatic ecosystem (Hna et al., 2004). The presence of both gastropods and bivalves are very significant in an aquatic ecosystem because they prepare food for fish and they connect an important link in the food chain. Molluscs are very sensitive indicator in localized condition, indicate the health of the ecosystem. It is a useful tool for monitoring (biological) of river by using macro invertebrate especially for the assessment of water quality (Rosenberg and Resh, 1993; Hellawell, 1986). From the sea face to Nabadwip (latitude $23^{\circ} 24^{\prime}$ and longitude $88^{0} 22^{\prime}$ ) about $295 \mathrm{~km}$. of the Hooghly Bhagirathi River is often referred as Hooghly estuary because of tidal influence due to its funnel shaped surface which is well suited for the optimum tidal flux (Menon et al., 1972 ).

The Hooghly- Bhagirathi river in the studied area is affected due to abstraction of large amount of water for industrial uses. Sewer outlets and drainages, which open into the river directly cause resource deterioration. The present study is mainly concerned with the population dynamics of macrobenthos as related to certain hydrobiological condition of the studied portion of the river particularly in view of its organic and industrial pollution.

The main objective of this study is to highlight the ecological status in the studied area of Hooghly-Bhagirathi River, to study the macrobenthic community of the studied stations, to find out the influence of abiotic factor on the macrofauna using statistical methods and to assess the different population attributes with special reference to community diversity.

In the above context, an attempt was made to study the above factor in the HooghlyBhagirathi river in the areas from Nabadwip (latitude $23^{0} \quad 24^{\prime}$ and logitude $88^{0} \quad 22^{\prime}$ ) to Raichak (latitude $22^{0} 12^{\prime}$ and longitude $88^{\circ} 07^{\prime}$ ) of West Bengal, India from June 2016 to May 2017.

\section{Materials and Methods}

\section{Study area}

Station-1 (Nabadwip): This station is located in the latitude $23^{0} 24^{\prime}$ and $88^{0} 22^{\prime}$ longitude. 
The river bed is not exposed except the summer season. Tidal flow is nearly absent.

Station-2 (Mayapur): This station is located in the latitude $23^{\circ} 24^{\prime}$ and $88^{\circ} 22^{\prime}$ longitude. The tidal influence is nearly absent in this station. Aquatic weeds mainly Eichornia crassipes is most dominant along the bank of the river. Here the river Jalangi meets with the main flow of the.

Station-3 (Khardaha): This station is located in between the latitude $22^{\circ} 12^{\prime}$ and longitude $88^{0} 48^{\prime}$. The mud flat of this station is also inundated and exposed during tide. But the tidal influence is less than station-4.

Station-4 (Raichak): This station is located in between the latitude $22^{0} 12^{\prime}$ and $88^{\circ} 07^{\prime}$ longitude. The mud flat of this site gets inundated and exposed during tide. Along the mud flat the bank of the station is supported by cemented wall.

\section{Collection of sample}

Stratified random quadrate sampling method was followed for quantitative assessment of molluscan fauna (Christian and Harris, 2005). At each sampling station four replicates were performed to overcome the problem of random sampling. An Ekman dredge of 22 $\mathrm{cm}^{2}$ was used for the collection of macrobenthic sample. Four samples were collected at random from studied area. All the samples collected were sieved through a standard sieve no. (256 mesh $\left./ \mathrm{cm}^{2}\right)$. The sample were preserved in $70 \%$ alcohol and used for identification. Molluscs were preserved in $75 \%$ alcohol and were identified (Ramakrishna and Dey, 2007). The density of molluscan species (number $/ \mathrm{m}^{2}$ ) in each sample was calculated according to the following formula (Clark et al., 1989 ).

$\mathrm{D}=(\mathrm{N} / \mathrm{n} \times 44)$
Where ' $D$ ' is density, ' $N$ ' is the number of specimen collected and " $\mathrm{n}$ ' is the no of grab samples. The frequency of occurrence of macrobenthic molluscan species has been calculated using F index (Guille, 1970).

$\mathrm{F}=\mathrm{P}_{\mathrm{a}} / \mathrm{Px} 100$

Where $\mathrm{P}_{\mathrm{a}}=$ number of stations where the species occurred and $\mathrm{P}=$ total number of station. The macrobenthic molluscan species were classified as - constant species ( $\mathrm{F}>$ $50 \%)$, common $(10 \%<\mathrm{F}<49 \%)$ and rare $(\mathrm{F}$ $<10 \%$ ) according to the above formula.

\section{Physico- chemical analysis}

Water parameters like DO, alkalinity, hardness, chloride, nitrate, phosphate were analysed seasonally following the standard method (APHA, 1989). Temperature were measured in the field with the help of thermometer (range $0^{\circ} \mathrm{C}-60^{\circ} \mathrm{C}$ ) while $\mathrm{pH}$ of water was determined by $\mathrm{pH}$ meter (Hanna, model no. H1 98107).

\section{Statistical analysis}

Different biological indices viz. ShannonWiener index (Shannon and Wiener, 1963), $\beta$ diversity or heterogeneity index (d) (Whittaker, 1975), Evenness index of diversity (E) (Pielou, 1966), Berger-Parker index (Berger and Parker, 1970) of dominance (d) were calculated to interpret species richness, dominance and species abundance. The relationship between species and physicochemical variables were evaluated by applying Principle component analysis (Ter Braak and CJF, 1995). GLM were applying to denote the main physicochemical parameters (McCullagh and Nelder, 1989). The similarities of species assemblage among different sampling stations were determined using Brays-Curtis index (Krebs, 1999). 


\section{Results and Discussion}

\section{Species composition and abundance}

The macrobenthic molluscan population in Hooghly-Bhagirathi River comprised 2 classes (Gastropoda and Bivalvia), 10 families and 16 species (Table 2). Gastropoda had 7 families and 12 species, while Bivalvia has 3 families and 4 species. Neritidae and Lymnaeidae had the highest species composition. Thiaridae and Unionidae has 2 species and all the other families had one species. The annual percentage contribution of malacofauna to the total molluscan species was higher in the class Bivalvia (56.41\%) than Gastropoda (43.59\%) (Fig. 2). This finding is very similar to the work of (Sakhare and Kamble, 2015). The annual percentage of species composition given in figure (Fig. 3 and 4). Among gastropoda dominant species shows that Tarebia lineata had (48.66\%) followed by Filopaludina bengalensis (24.51 \%), Brotia costula (7.11\%), Neritina smithii (5.86 \%) respectively. Among Bivalvia dominant species shows that Novaculina gangetica had (97.51\%) followed by Lamellidens marginalis $(1.16 \%)$. According to the frequency of occurrence (F value) eight gastropod species Neripteron violacecum, Neritina smithii, Filopaludina bengalensis, Assiminea francesiae, Tarebia lineata, Brotia costula, Radix luteola, Indoplanorbis exustus and three species of bivalves, viz, Lamellidens marginalis, Parreysia favidens, Corbicula striatella are considered as constant species. The remaining four species of gastropods Septaria lineata, Melanoides tuberculata, Radix acuminata, Radix ovalior and one species of bivalves Novaculina gangetica are classified as common species. The distribution of molluscan population in relation to station and season (Fig. 5, 6, 7, 8) showed that Station-2 had the highest number of species composition (10 species) and the dominant species Novaculina gangetica had the abundance 414 nos. $/ \mathrm{m}^{2}$ and the total average abundance was 453 nos. $/ \mathrm{m}^{2}$. In case of station1 total average abundance was 53 nos. $/ \mathrm{m}^{2}$ and the dominant species Tarebia lineata has the abundance of 28 nos. $/ \mathrm{m}^{2}$ followed by Filopaludina bengalensis $\left(11 \mathrm{nos} . / \mathrm{m}^{2}\right)$. In case of Station-3 and station-4 total average abundance was 144 nos. $/ \mathrm{m}^{2}$ and 115 nos. $/ \mathrm{m}^{2}$ respectively.

\section{Physico -chemical parameters}

The $\mathrm{pH}$ of water was found to be alkaline in all stations varying from 7.2 to 8.05 . Hooghly Bhagirathi River seems to have a good buffering capacity so it maintains the fluctuation in the entire stretch (Ray and Ghosh, 1976). The current in lotic environment tends to keep the $\mathrm{pH}$ uniform over certain distance (Welch, 1952). Maximum water temperature was recorded in the month of April - May $\left(30^{\circ} \mathrm{C}-34^{\circ} \mathrm{C}\right)$ and the minimum temperature in the month January and February $\left(22^{\circ} \mathrm{C}-26^{\circ} \mathrm{C}\right)$. The values of alkalinity varied from 91-335, 91$335,97-231,210-378 \mathrm{mg} / \mathrm{l}$ at station $1-4$ respectively. High alkalinity is an indication of pollution (Kulshrestha et al., 1989). Higher alkalinity noticed at station- 4 because of high concentration of sewage (Robert, 1977; Das and Sinha, 1994). Water Hardness varied from 90-274, 90-274, 97-174, 102-490 $\mathrm{mg} / \mathrm{l}$ at station $1-4$ respectively. Based on mean value of hardness station $1-3$ fall under moderately hard water while station- 4 fall under moderately hard to hard water. The high value of hardness indicates the high pollution load of sewage (Sharma et al., 1981). The value of dissolved oxygen varied from 7.0 $9.2 \mathrm{mg} / \mathrm{l}$ at station- 1 and station- 2, $6.5-9.0$ $\mathrm{mg} / \mathrm{l}$ at station 3 and $6.5-8.0 \mathrm{mg} / \mathrm{l}$ at station4. Chloride content of the river varied from $16-38 \mathrm{mg} / \mathrm{l}$ in station 1 and $2,18-39 \mathrm{mg} / \mathrm{l}$ at station 3, and $62-333 \mathrm{mg} / \mathrm{l}$ at station- 4 . In general station- 4 showed high chloride content as the station is nearer to Bay of 
Bengal. As nutrients are directly related to productivity concentration of nutrients like nitrogen and phosphate are important in lotic ecosystem. The phosphate content in the present study varied from $0.1-0.40 \mathrm{mg} / \mathrm{l}$ at station- 1, station- 2 and station- 3 and 0.05 $0.45 \mathrm{mg} / \mathrm{l}$ at station- 4 respectively. Nitrate was not detectable at station- 3 and station- 4; on the other hand at station-1 and station- 2 the concentration of nitrate varied from 0 $0.15 \mathrm{mg} / \mathrm{l}$ (Table 1).

\section{Biological indices}

The macrobenthic molluscan fauna was analyzed for species diversity, species dominance, species richness and evenness (Fig. 9). The value of Shannon-Wiener index ranged from 0.75 to 1.25 with an average of 1.0. The evenness index varied from 0.23 to 0.54 with an average of 0.43 . The BergerParker dominance index varied from 0.52 to 0.83 with an average value of 0.66 . Dominance index indicates the degree of predominance of one or a few species in an ecological habitat. As dominance index increases in an ecosystem, diversity index decreases which may be caused by increasing aquatic pollution. In higher level of pollution, only a few species can tolerate and survive and later flourish to increase their population abundance due to better adaptation to the changed environment and reduced competition from other species. $\beta$ - diversity index ranged from 0.25 to 0.55 with average of 0.41 . Overall, according to the result found low diversity index, the uneven distribution of species, low evenness value and moderate dominance showed an unstable community structure at the study sites of Hooghly Bhagirathi River.

\section{Statistical analysis}

Cluster (Dendrogram) analysis of the selected stations (Fig. 11) showed one prominent cluster and two intermediate cluster. Prominent cluster formed between station- 3 and station-4. Bray- Curtis index is 0.6 of these two stations in respect of their annual species assemblage. From the intermediate cluster it was seen that station- 1 exhibits less similarity to complete cluster and the Braycurtis index is 0.38 in between Station-1 and the complete cluster. Station 2 has least similarity to other three stations with BrayCurtis index 0.12. Cluster analysis has clearly shown affinities between sample and thus providing a baseline for monitoring programme.

Individual rarefaction estimates how many taxa is expected in a sample with smaller amount of individual. With this method (algorithm is from Krebs 1969), it can be compared the no. of taxa in sample of different size. Standard error are calculated and converted to 95 percent confidence interval. The rarefaction curve shows the possibility to find out maximum taxa in station- 2 followed by station-3, station- 2 and station-4. The highest species abundance is seen in station-2 followed by station-4, station-3 and station-1. Rarefaction curve indicate that the highest sampling is needed to find out the possible all taxa in case of station2 followed by station-4, station- 3 and station1.

PCA analysis shows first two principle component $22.31 \%$ and $16.69 \%$ variability with eigenvalue 5.35 and 4.00 respectively. To form principle component 1 Radix acuminate, Radix ovalior, Radix luteola, Lamillidens marginalis, Novaculina gangetica contribute most and in case of component 2 Septaria lineata, Filopaludina bengalensis, Assiminea francesiae, Brotia costula has major responsibility. Among water parameter salinity contribute highest to component 1 and for component 2 it is hardness of water. From Biplot analysis phosphate, salinity and 
alkanity shows close association. Neripteron violaceum, Neritina smithii also makes a cluster with these factors. Especially Neritina smithii is very good indicator of phosphate and Neripteron violaceum for salinity. Septaria lineata and Assiminea francesiae are almost similar in relation with other factors. Brotia costula, Filopaludina bengalensis, Melanoides tuberculata are more or less similar with Septaria lineata, Assiminea francesiae group. $\mathrm{pH}$ and salinity shows inverse relation that is also consistent with Neripteron violaceum,Neritina smithii group. Novaculina gangetica, Radix luteola, Lamillidens marginalis, Radix ovalior, Radix acuminata are almost similar in terms of population variability with other factors; DO is the most sensitive factor for this large group. Water temperature and nitrate are clearly in inverse relationship.

GLM (General Linear Modelling) have been done in considering gastropod and bivalve abundance as dependent variable and water parameter as independent variable. Univariate result shows that salinity $(p=0.03)$ and alkalinity $(\mathrm{p}=0.01)$ is most important factor for gastropod species and for bivalve it is $\mathrm{pH}$ $(p=0.02)$ and phosphate $(p=0.03)$. The phosphate content of water influences the total benthic organisms which are in conformity with the findings of Adholia et al., (1990). In case of multivariate test of significance, Wilks's lambda distribution found most significant $(\mathrm{p}=0.04)$ for alkalinity. Sarkar (1989) reported a positive relation between alkalinity and molluscan population. Observed power for independent variables in an ascending order of temperature, DO, nitrate, hardness, salinity, $\mathrm{pH}$, phosphate and alkalinity. Test result for whole model for gastropod and bivalve are well significant (Table 3) and shows $\mathrm{R}^{2}$ value 0.42 and 0.36 respectively. Predicted vs. observed result according to derived linear equation (Chart-1) shows satisfactory result (Fig. 14 and 15).

Table.2 Mean \pm Standard deviation of Physico - chemical parameters of Hooghly-Bhagirathi river

\begin{tabular}{|l|l|l|l|l|l|}
\hline & Parameters & Station 1 & Station 2 & Station 3 & Station 4 \\
\hline 1. & $\begin{array}{l}\text { Dissolved } \\
\text { oxygen }(\mathrm{mg} / \mathrm{l})\end{array}$ & $7.9 \pm 0.66$ & $7.9 \pm 0.66$ & $7.6 \pm 0.722$ & $7.9 \pm .54$ \\
\hline 2. & $\begin{array}{l}\text { Temperature } \\
\left({ }^{0} \mathrm{C}\right)\end{array}$ & $29.24 \pm 4.21$ & $29.24 \pm 4.21$ & $29.87 \pm 3.05$ & $30.00 \pm 2.23$ \\
\hline 3. & Water $\mathrm{pH}$ & $7.6 \pm 0.32$ & $7.6 \pm 0.32$ & $7.7 \pm 0.15$ & $7.6 \pm .16$ \\
\hline 4. & Salinity $(\mathrm{mg} / \mathrm{l})$ & $24.62 \pm 7.37$ & $24.62 \pm 7.37$ & $25.83 \pm 7.27$ & $208.36 \pm 106.48$ \\
\hline 5. & $\begin{array}{l}\text { Hardness } \\
(\mathrm{mg} / \mathrm{l})\end{array}$ & $128 \pm 54.17$ & $128 \pm 54.17$ & $121 \pm 33.50$ & $232 \pm .125 .49$ \\
\hline 6. & $\begin{array}{l}\text { Alkalinity } \\
(\mathrm{mg} / \mathrm{l})\end{array}$ & $198.76 \pm 101.275$ & $198.76 \pm 101.275$ & $161.73 \pm 46.89$ & $281.36 \pm .66 .02$ \\
\hline 7. & $\begin{array}{l}\text { Phosphate } \\
(\mathrm{mg} / \mathrm{l})\end{array}$ & $0.17 \pm 0.05$ & $0.17 \pm 0.05$ & $0.16 \pm 0.04$ & $0.31 \pm 0.08$ \\
\hline 8. & Nitrate $(\mathrm{mg} / \mathrm{l})$ & $0.014 \pm 0.04$ & $0.014 \pm 0.04$ & 0 & 0 \\
\hline
\end{tabular}


Table.1 Species of Bivalves and Gastropods found at the studied sites

\begin{tabular}{|c|c|c|c|c|c|c|}
\hline \multirow[t]{2}{*}{ Class } & \multirow[t]{2}{*}{ Order } & \multirow{2}{*}{$\begin{array}{l}\text { Family } \\
\text { Genus Species }\end{array}$} & \multicolumn{4}{|c|}{ 2016-2017 } \\
\hline & & & Site 1 & Site 2 & Site 3 & Site 4 \\
\hline \multirow[t]{7}{*}{ Gastropoda } & Cycloneritimorpha & $\begin{array}{l}\text { Neritidae } \\
\text { 1.Neripteron violaceum } \\
\text { 2.Neritina smithii } \\
\text { 3.Septaria lineata }\end{array}$ & $\begin{array}{l}- \\
- \\
-\end{array}$ & $\begin{array}{l}- \\
- \\
-\end{array}$ & $\begin{array}{l}+ \\
+ \\
+\end{array}$ & $\begin{array}{l}+ \\
+ \\
-\end{array}$ \\
\hline & Architaenioglossa & $\begin{array}{l}\text { Viviparidae } \\
\text { 4.Filopaludina bengalensis }\end{array}$ & + & + & + & + \\
\hline & Littorinimorpha & $\begin{array}{l}\text { Assimineidae } \\
\text { 5.Assiminea francesiae }\end{array}$ & - & - & + & + \\
\hline & Caenogastropoda & $\begin{array}{l}\text { Thiaridae } \\
\text { 6.Melanoides tuberculata } \\
\text { 7.Tarebia lineata }\end{array}$ & $\begin{array}{l}+ \\
+\end{array}$ & $\begin{array}{l}- \\
+\end{array}$ & $\begin{array}{l}+ \\
+\end{array}$ & $\begin{array}{l}- \\
+\end{array}$ \\
\hline & Caenogastropoda & $\begin{array}{l}\text { Pachychilidae } \\
\text { 8.Brotia costula }\end{array}$ & + & + & + & - \\
\hline & Hygrophila & $\begin{array}{l}\text { Lymnaeidae } \\
\text { 9. Radix acuminata } \\
\text { 10. Radix ovalior } \\
\text { 11. Radix luteola }\end{array}$ & $\begin{array}{l}- \\
- \\
+\end{array}$ & $\begin{array}{l}+ \\
+ \\
+\end{array}$ & $\begin{array}{l}+ \\
+ \\
+\end{array}$ & $\begin{array}{l}- \\
- \\
-\end{array}$ \\
\hline & Hygrophila & $\begin{array}{l}\text { Planorbidae } \\
\text { 12.Indoplanorbis exustus }\end{array}$ & + & + & + & - \\
\hline \multirow[t]{3}{*}{ Bivalvia } & Unionoida & $\begin{array}{l}\text { Unionidae } \\
\text { 13.Lamellidens marginalis } \\
\text { 14.Parreysia favidens }\end{array}$ & $\begin{array}{l}+ \\
+\end{array}$ & $\begin{array}{l}+ \\
+\end{array}$ & $\begin{array}{l}- \\
-\end{array}$ & $\begin{array}{l}- \\
-\end{array}$ \\
\hline & Adapedonta & $\begin{array}{l}\text { Pharidae } \\
\text { 15.Novaculina gangetica }\end{array}$ & - & + & - & - \\
\hline & Veneroida & $\begin{array}{l}\text { Cyrenidae } \\
\text { 16. Corbicula striatella }\end{array}$ & + & + & + & - \\
\hline
\end{tabular}

Table.3 Test of SS Whole Model vs. SS Residual (glm new.xlsx (C3:AX50)

\begin{tabular}{|l|l|l|l|l|l|l|l|l|l|l|l|}
\hline $\begin{array}{l}\text { Dependent } \\
\text { variable }\end{array}$ & $\begin{array}{l}\text { Multiple } \\
\text { R }\end{array}$ & $\begin{array}{l}\text { Multiple R } \\
\text { square }\end{array}$ & Adjusted & SS & Df & MS & SS & df & MS & F & P \\
\hline Gastropod & 0.649695 & 0.422103 & 0.300441 & 736397.3 & 8 & 92049.66 & 1008194 & 38 & 26531.42 & 3.469459 & 0.004268 \\
\hline Bivalve & 0.601829 & 0.362198 & 0.227924 & 791268.6 & 8 & 98908.58 & 1393359 & 38 & 36667.33 & 2.697458 & 0.018677 \\
\hline
\end{tabular}


Fig.1 Map shows the study area
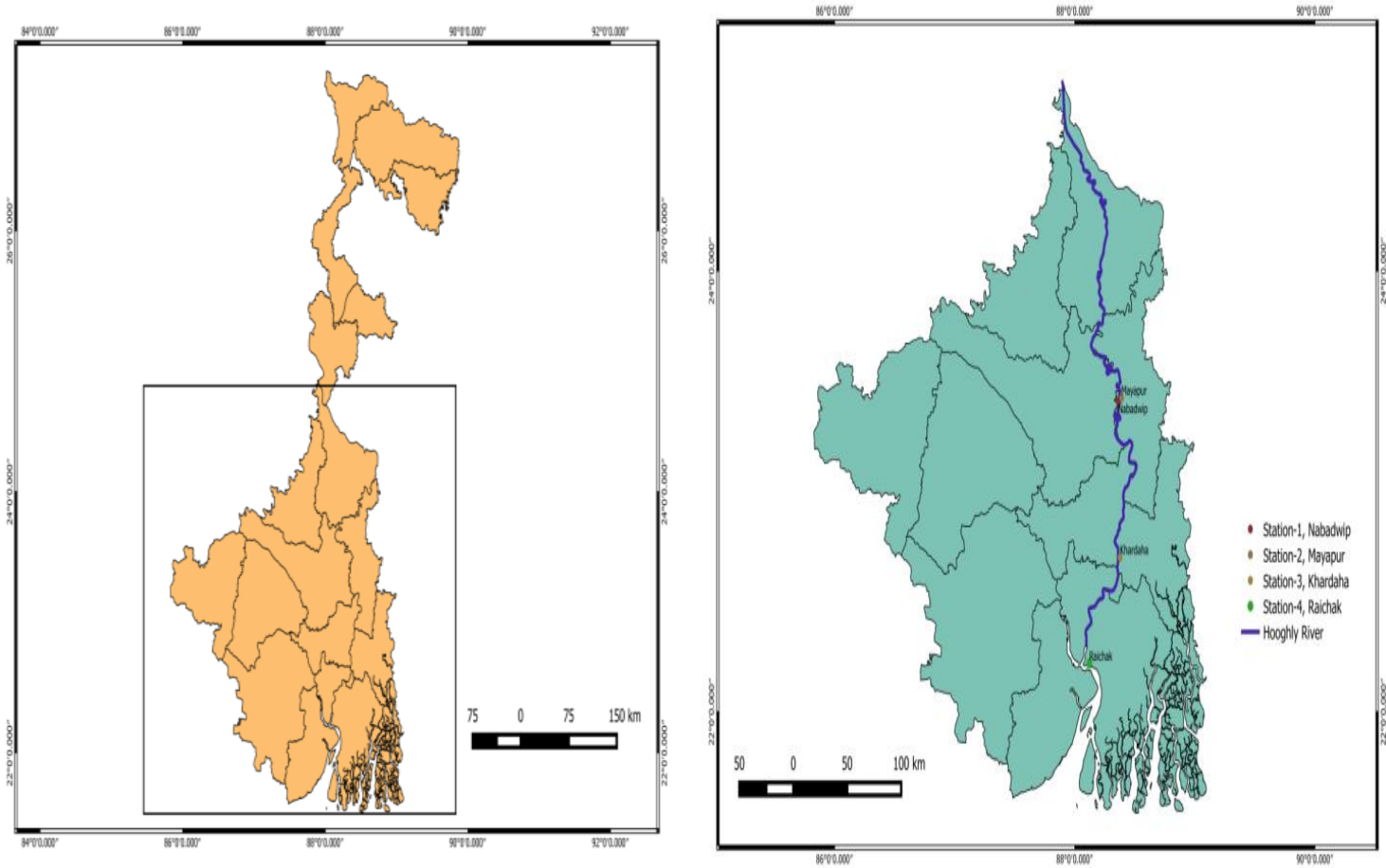

Fig.2 Total annual percentage composition of class Bivalvia and Gastropoda

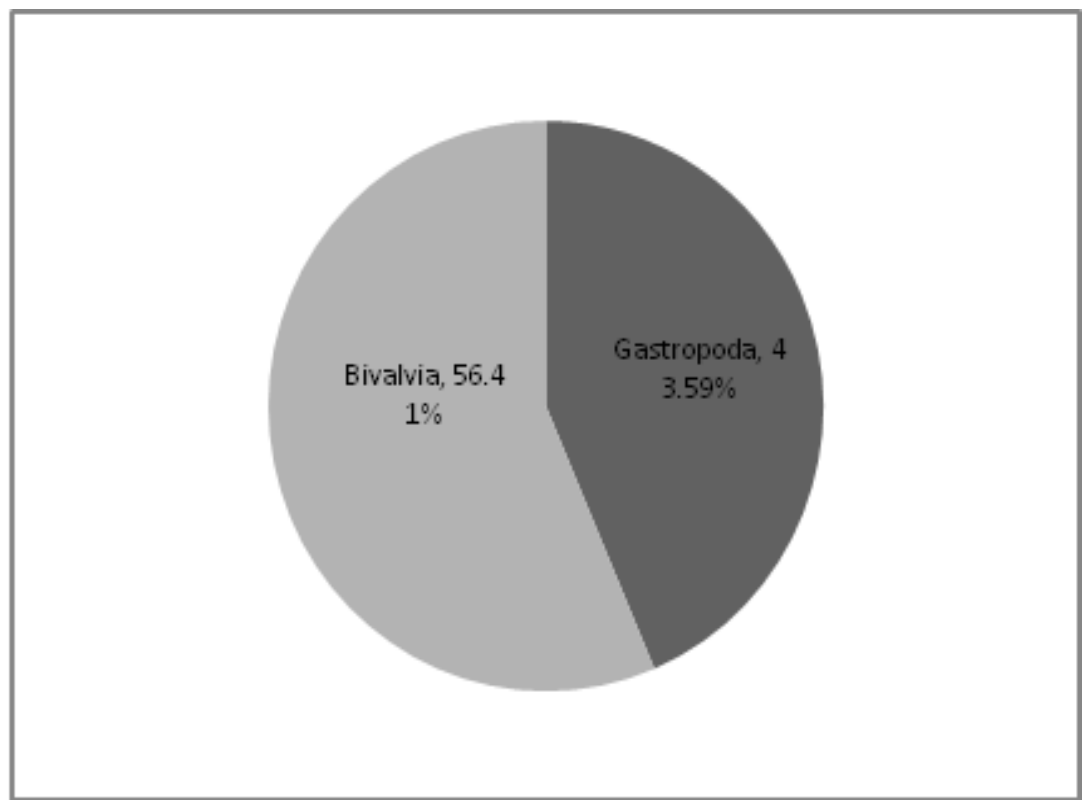


Fig.3 Percentage of annual composition of individual

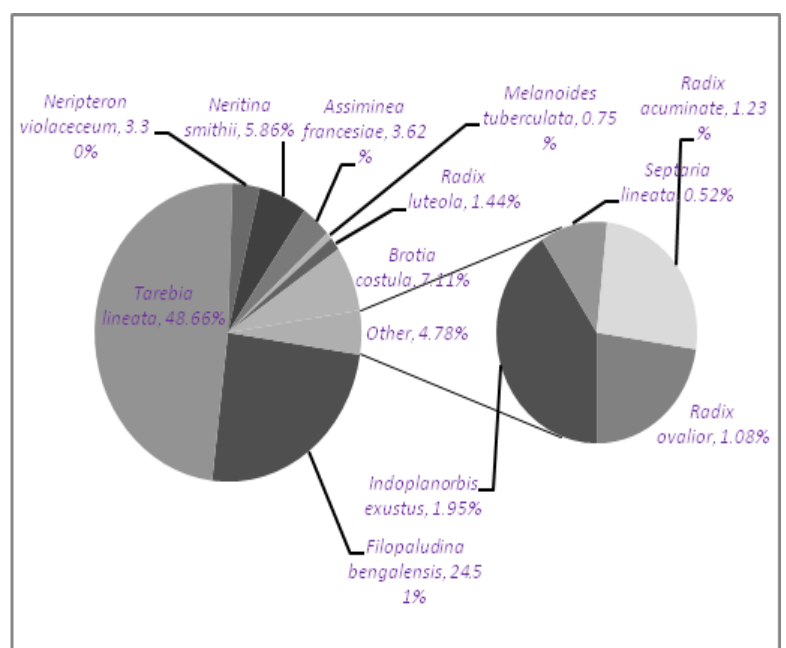

Fig.4 Percentage of annual composition of individual

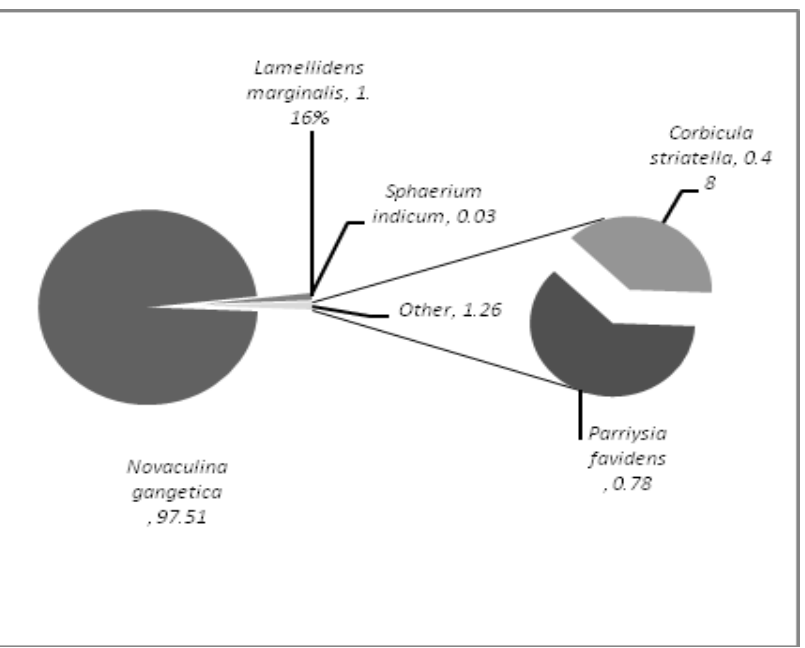

Fig.5 Abundance (nos. $/ \mathrm{m}^{2}$ ) of individual species at (Stn- 1) in different season

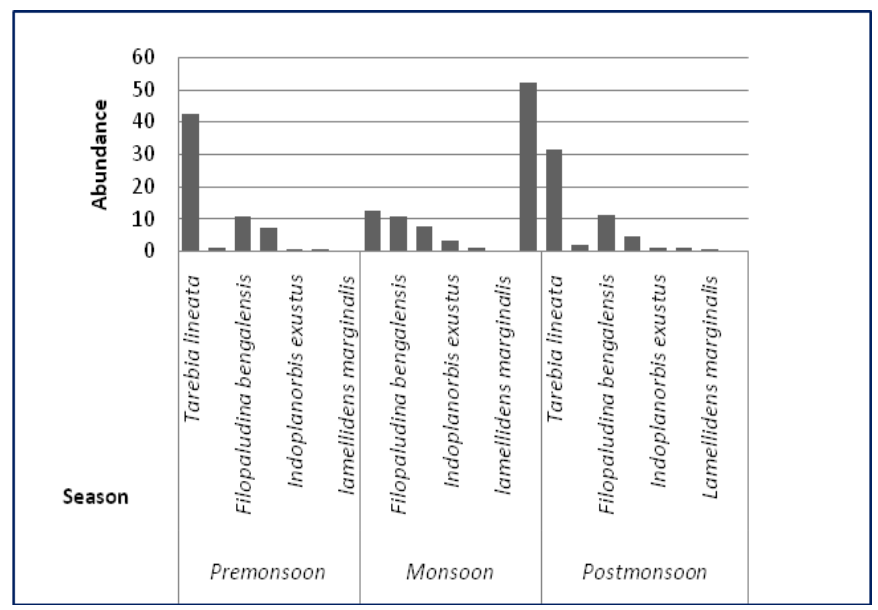

Fig. 6 Abundance $\left(\right.$ nos. $\left./ \mathrm{m}^{2}\right)$ of individual species at (Stn-2) indifferent season

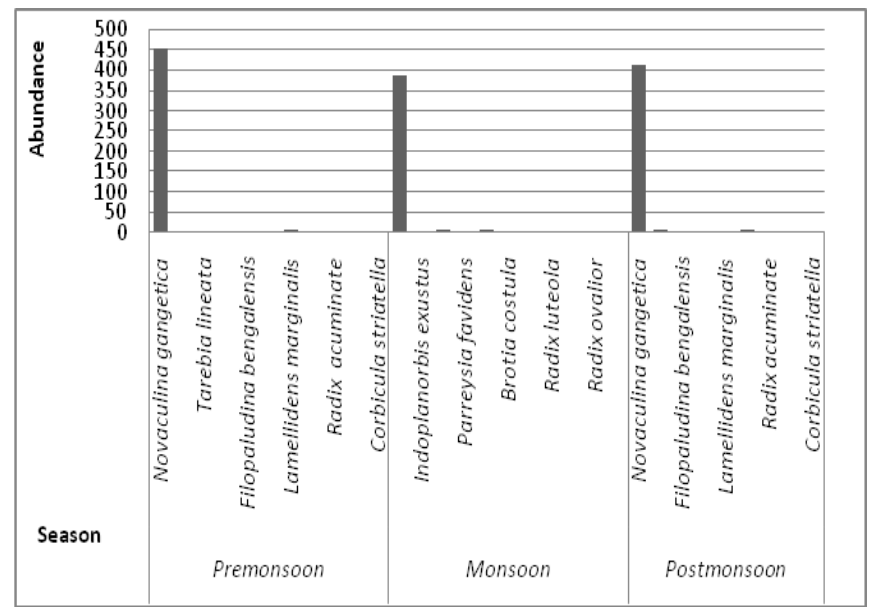


Fig.7 Abundance (nos./ $\mathrm{m}^{2}$ ) of individual species found in different season at (stn-3)

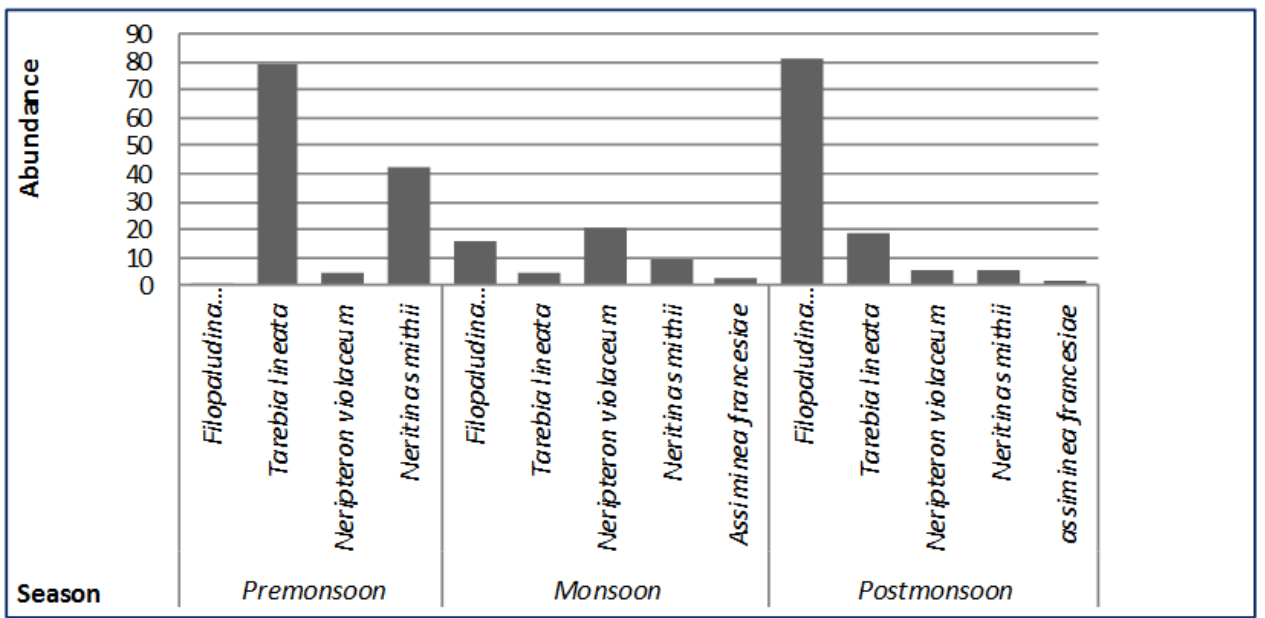

Fig. 8 Abundance (nos./ $\mathrm{m}^{2}$ ) of individual species found in different season at (Stn-4)

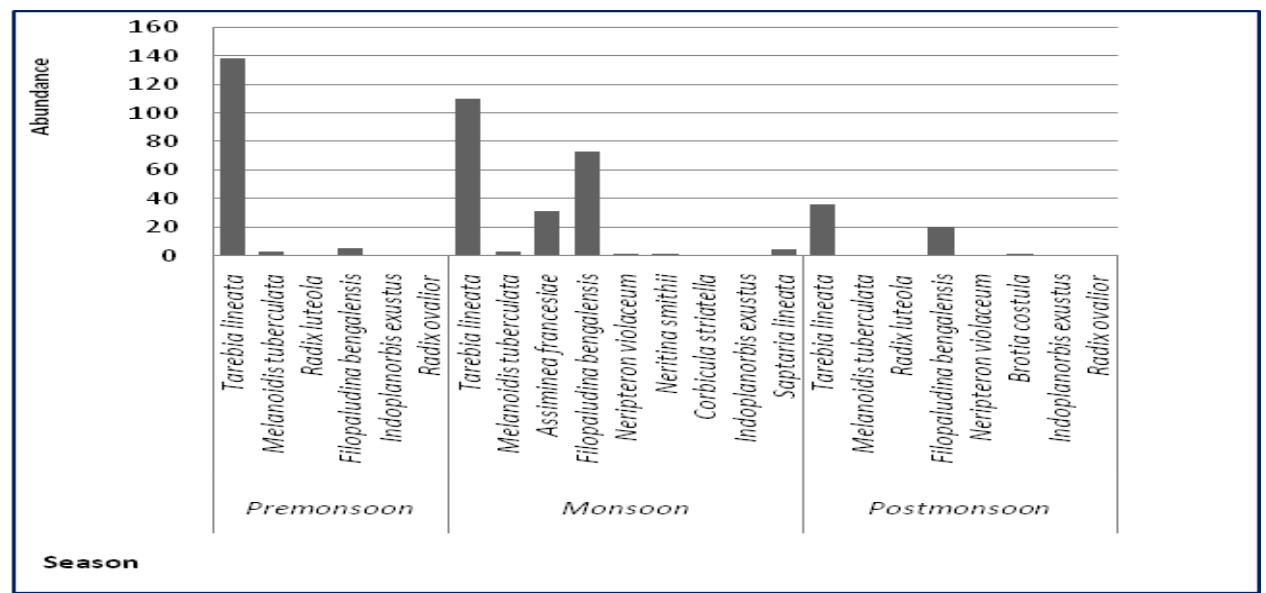

Fig. 9 Abundance (nos./ $\mathrm{m}^{2}$ ) of total Macrobenthic fauna (Gastropod and Bivalve) at four stations in different seasons

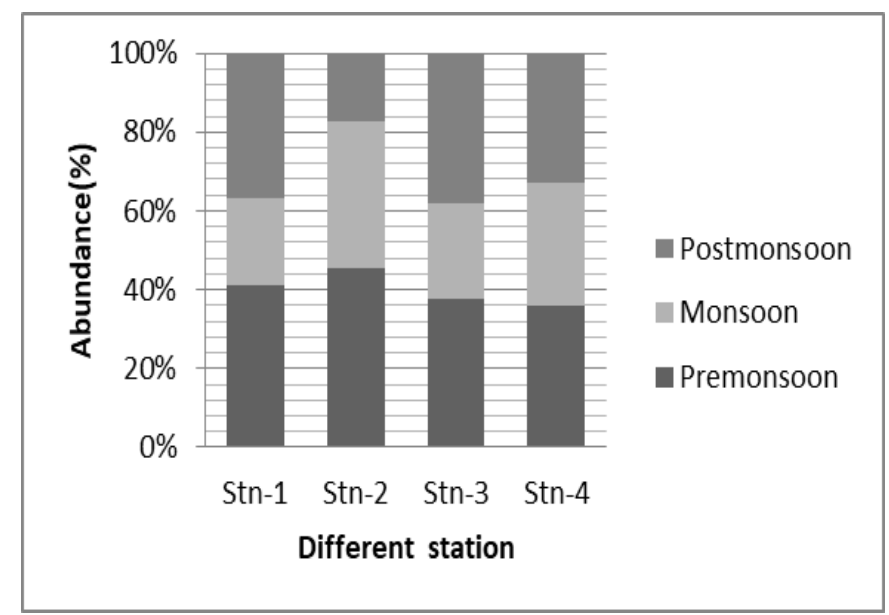


Fig.10 Mean value of different diversity indices at different sites in different month

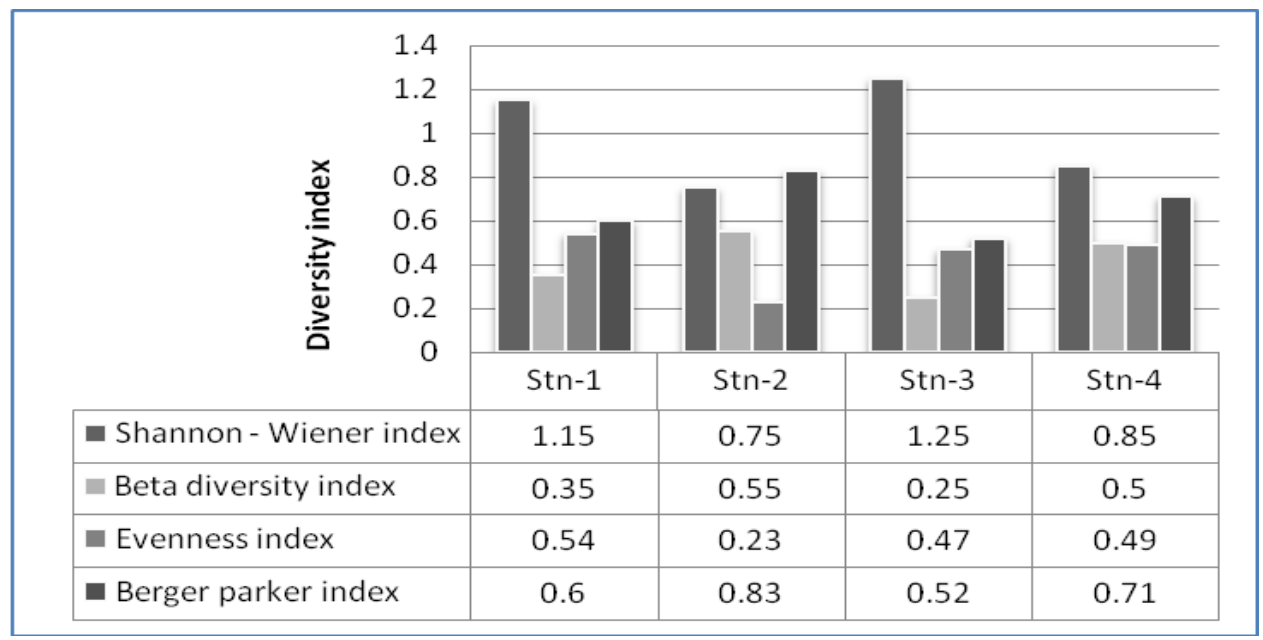

Fig.11 Dendrogram using Bray-Curtis coefficient and complete linkage clustering with the sampling stations

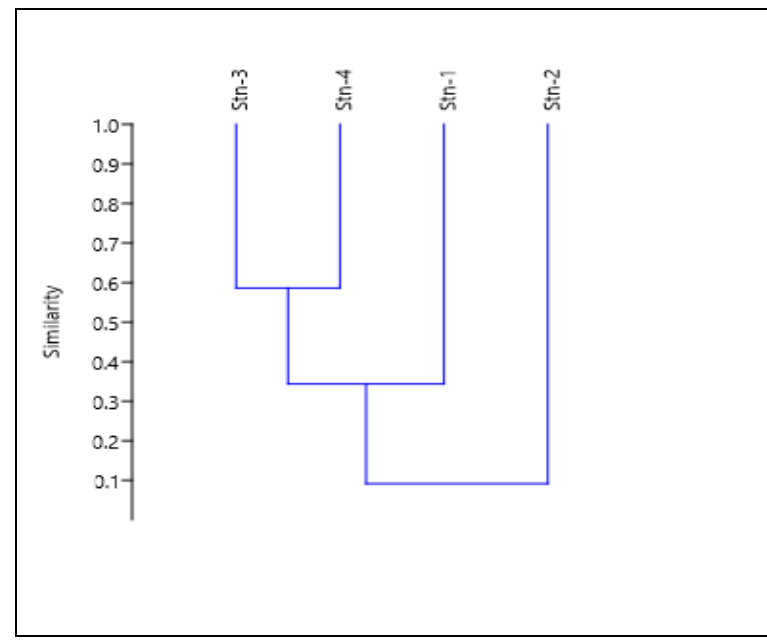

Fig.12 Rarefaction curve of sampling taxa at different sampling sites

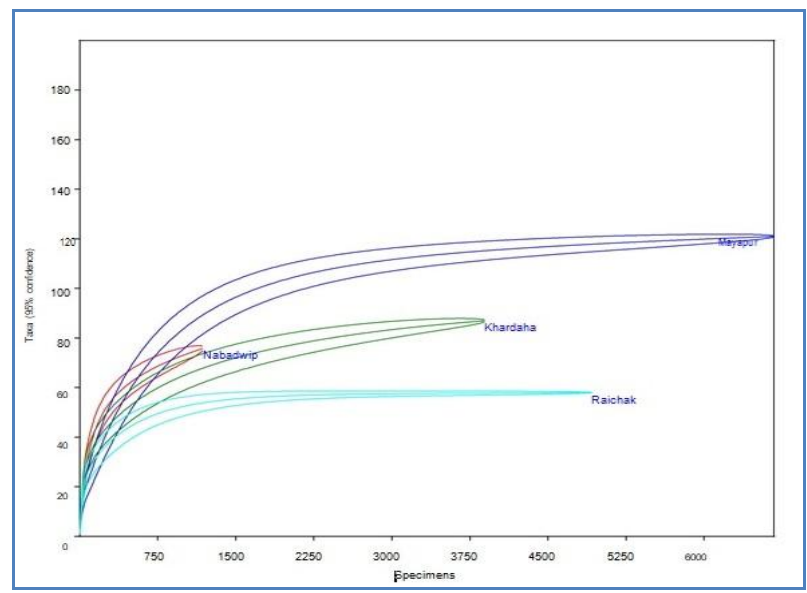


Fig.13 Principle Component Analysis of macrobenthic fauna as affected by different physicochemical parameters of water of Ganga River. (Sp1-Neripteron violaceum, Sp2- Neritina smithii, Sp3-Septaria lineata, Sp4-Filopaludina bengalensis, Sp5-Assiminea francesiae, Sp6-Melanoides tuberculata, Sp7 -Tarebia lineata, Sp8-Brotia costula, Sp9-Radix acuminata, Sp10-Radix ovalior, Sp11-Radix luteola, Sp12-Indoplanorbis exustus, Sp13-Lamillidens marginalis, Sp14-

Parreysia favidens, Sp15-Novaculina gangetica, Sp16-Corbicula striatella).

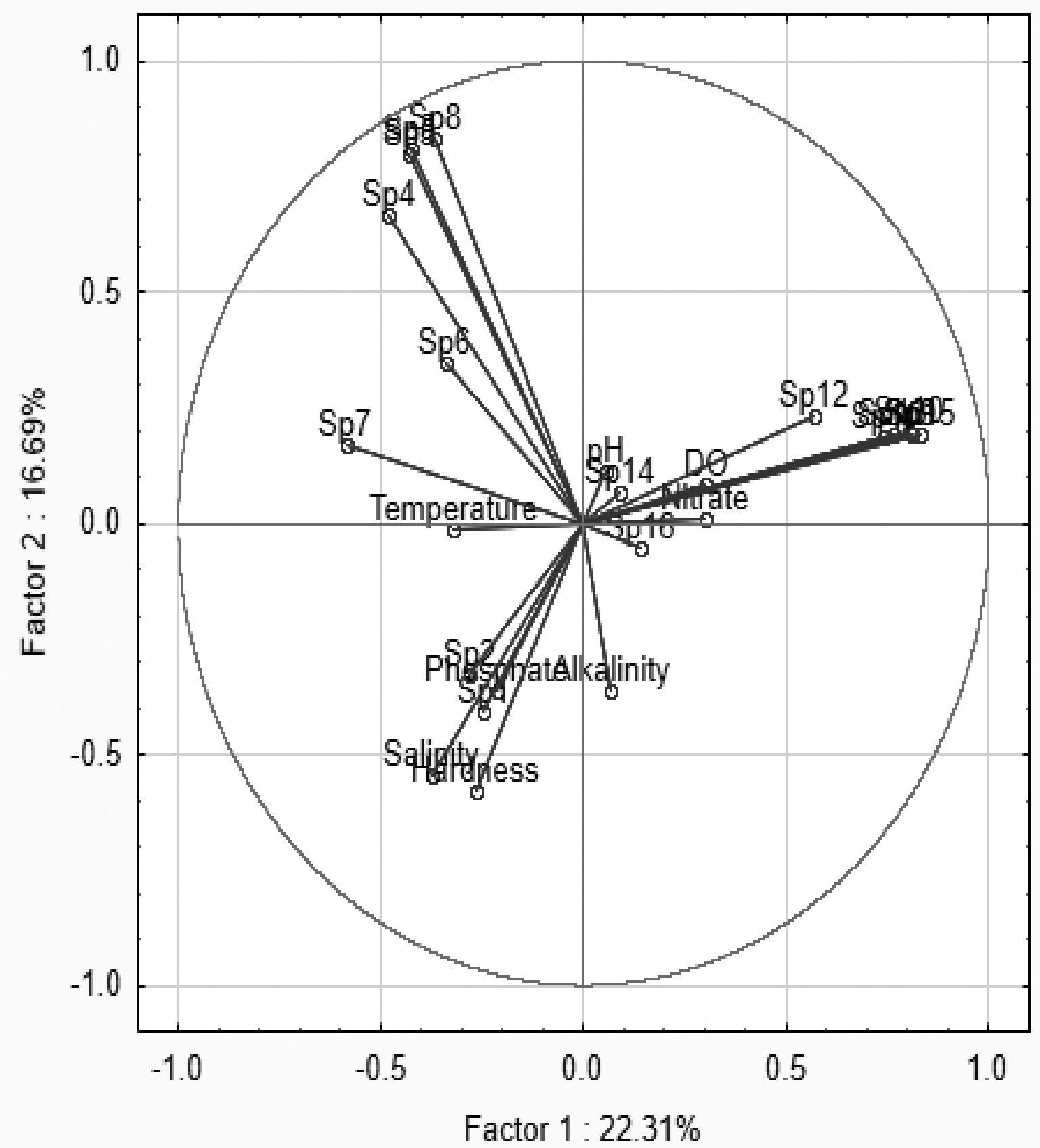


Fig.14 Graph of observed vs predicted for Gastropod $\left(\mathrm{R}^{2}=0.42\right)$

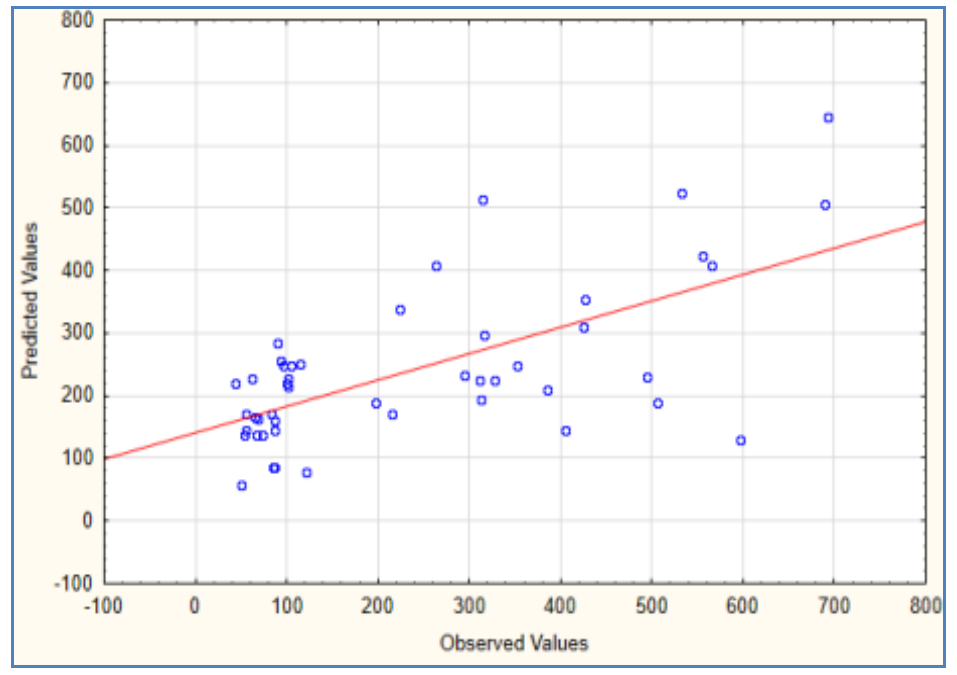

Fig.15 Graph of observed vs predictedfor Bivalve $\left(\mathrm{R}^{2}=0.36\right)$

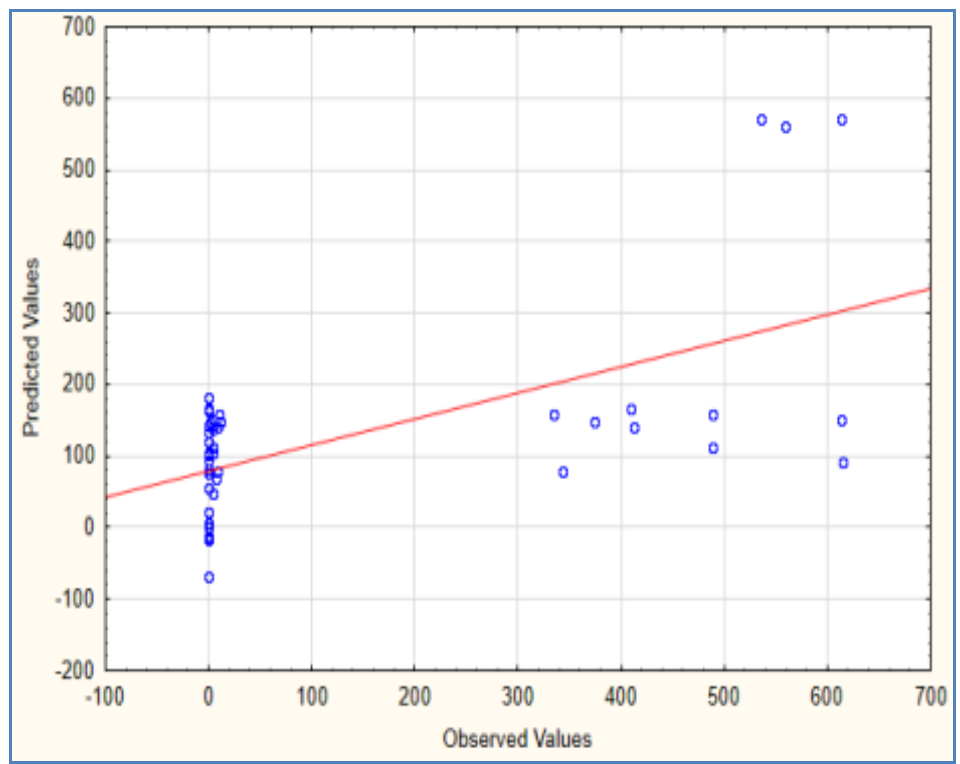

In conclusion, the diversity of molluscs at four localities of Hooghly-Bhagirathi river varied significantly. During the study period $43.59 \%$ of gastropod species and $56.41 \%$ of bivalve species were recorded. Tarebia lineata and Filopaludina bengalensis were the most ubiquitous, being present in all stations. They are the indicator species because of their wide distribution and pollution tolerance level. Neritina smithii is primarily a brackish water species occasionally extending in to fresh water and is found in station-4 and Station-3 probably due to habitat fragmentation. Assiminea francesiae is the only species of Assimineidae that is found in fresh water within the area of tidal influence (Ramakrishna and Dey, 2007) in our present study this is found in station- 4 and station- 3 . Fresh water bivalves are very sensitive to salinity so the distribution of fresh water 
bivalve (Family- Pharidae, Unionidae, Cyprinidae) are mainly found in station-1 and 2 due to absolutely fresh water habitat but they are not present in station- 3 and 4 as salinity gradually increases. As per the species diversity scale of Wilhm and Doris (1968) $(\mathrm{H}>3=$ clean water, $\mathrm{H}=1-3=$ moderately polluted, $\mathrm{H}<1$ = heavily polluted) station- 1 and 3 are moderately polluted where as station-2 and 4 are heavily polluted. According to the Berger - Perker index if aquatic pollution increases dominance index increases but diversity index decreases. Higher Berger-Parker dominance index signifies higher level of aquatic pollution which is found at station-2 and 4 than station1 and 3. The higher value of diversity index indicates greater perturbations due to environmental disturbances or pollution stress (Sharma et al., 2005; Padmanabha and Belagali, 2007) which is found in station-2 and 4. This indicates that station-1 was with highest equal representation of species and station-2 with lowest equal representation or highest unequal representation of species (Padmanabha and Belagali 2006, 2007). Among the physico-chemical parameters salinity $(\mathrm{mg} / \mathrm{l})$ and alkalinity $(\mathrm{mg} / \mathrm{l})$ are the most dominant factor for distribution of gastropods where as $\mathrm{pH}$ and phosphate $(\mathrm{mg} / \mathrm{l})$ play the same role in case of bivalves. The present study shows that recorded all molluscan species in the category of indigenous species with valuable biodiversity potency which needs to be conserved in relation to maintain the ecological balance and their sustenance in the nature. The study focus in the interrelationship between the varied seasonal parameters with biodiversity context.

\section{Aknowledgement}

Authors are grateful to Department of Higher Education, Science and Technology and Biotechnology, Govt. of West Bengal for providing fund in Major Research Project (Memo No. 696 (Sanc.) /ST/P/S and T/5G1/2004) and to the Principal, Serampore College for giving permission to do the work. Thanks are due to Dr.Tulica Biswas, Zoological Survey of India (Molluscan Department), Kolkata for kind help.

\section{References}

Adholia, U.N., Chakravarthy, A., Shrivastava, V., and Vyas, A. 1990. Community studies on macrozoobenthos with reference to limnochemistry of Manasarovar reservoir, Bhopal. J. Nature C;on., 2(2): 139-154.

APHA 1989. Standard Methods for the Examination of Water and Waste Water. $17^{\text {th }}$ edition, Washington, DC

Berger, W.H., and Parker, F.L. 1970. Diversity of planktonic Foraminifera in deep-sea sediments. Science 168: 1345-1347.

Boodninathan, M., Ravikumar, G., Chandran, M.D.S., and Ramachandra, T. 2012. Mangrove associate molluscs of India. In. National Conference on Conservation and Management of wetland Ecosystem, Lake.

Christian, A.D. and Harris, J.L. 2005. Development and assessment of a sampling design for mussel assemblages in large streams. Am. Midl. Nat., 153: 284-92.

Clark, F., Beeby, A., and Kirby, P. 1989. A study of the macroinvertebrates of Lakes Naivasha, Oloiden and Sonachi, Kenya. Revue d'Hydrobiolgie Tropicale., 22: 21-33.

Das, N.K. and Sinha, R.K., 1994. Pollution status of river Ganga at Patna (Bihar) India. J. Freshwater Bio., 6: 159-164.

Dey, A. 2006-2009. Hand book on Mangrove Associate Molluscs of Sunderbans. Zoological survey of India, Kolkata .

Ellen, E., Olivier, Gargominy, Wntston, F.P., 
Philippe, Bouchet. 2008. Global diversity of gastropods (Gastropoda; molluscs) in freshwater. Hydrobiologica., 595: 149-166.

Geller, J.B. 1991. Gastropods grazer and algal colonization on the rocky shore in northern California; the importance of the body grazer. J. Exp. Mar. Biol. Ecol., 150: 1-17.

Goldberg and Edward, D. 1986. The mussel watch concept. Environ Monit Assess., 7: 91-103.

Guille, A. 1970. Benthic bionomy of continental shelf of the French catalane coast. II. Benthic communities of the macrofauna. Vie Milie., 21: 239-25.

Hellawell, J.M. 1986. Biological Indicators of Freshwater Pollution and Environment Management. Elsiver Applied Science., 14: 188.

Hily, C., Connas, S., Raffin C Wyllie. and Echeverria, S. 2004. In vitro experiment assessment of the grazing marine L. epiphytic algae. Aquat. Bot., 78:183-195

Hna Louise, Mcivor, David Aldrige and Stephan Muller. 2004. Fresh water Mussel as Biofilters. PhD dissertation, Pembroke college. University of Cambridge.

Hofmann, W. 1978. Analysis of animal microfossils from the Grosser Segebergersee (F. R. G.). Arch. Hydrobiol., 82 (1-4): 316-346.

Jenkins, B.R.. and Hartnoll, R.G. 2001. Food supply, grazing activity and growth rate in the limpet Patella Vulgata L, a comparison between exposed and sheltered shore. J. Exp. Mar. Biol. Ecol., 258: 123-139.

Kelaher, B.D., Casilla, J.C., ParboL, Yurk, P., Schiwin, dt E. and Bortolus, A. 2007. Spatial variation in molluscan assemblages from coralline Teerfs of Argentinean Patagonia. J. Molluscan
Stud., 73: 133-146.

Kesavan, K., Palpandi, C. and Shanmugam, A. 2009. A Cheklist of malacofauna of the Vellar Estuarine Mangrove , India,J Threat Taxa., 1: 382-384.

Krebs, C.J. 1999. Ecological methodology. 2nd ed. Menlo Park: Benjamin Cummings.Total pages 620 .

Kulshresta, S.K., Adholia. U.N., Khan, A.A., Bhatnagar, A., Saxena, M. and Baghail, M. 1989. Pollution study on river Kshipra with special reference to macrozoobenthos. Nature Con., 1: 285-292.

Loh, J., Randers, J., MacGillivray, A., Kapos, V., Jenkins, M., Groombridge, B.,Cox, N. 1998. Living Planet Report. Gland, Switzerland, World Wide Fund for Nature., pp 56.

McCullagh, P. and Nelder, J.A. 1989. Generalized linear models. Chapman and Hall, London.

Menon, A.G.K., Rao, K.V. and Sen, T.K. 1972. The Hooghly and its fisheries in the past, the present and the future with special reference to the Farakka barrage on the Ganga. Sci Cult., 38: 338-343.

Pace, M.L., Shimmel, S. and Darley, W.M. 1979. The effect of grazing by gastropod, Nassarius obosletus on the benthic microbial community of a salt marsh mudflat. Estuar. Coast. Mar. Sci., 2: 121-134.

Padmanabha, B. and Belagali, S.L.2006. Comparative study on population dynamics of rotifers and water quality index in the lakes ofMysore. Nat. Env. Poll. Tech., 5(1): 107-109.

Padmanabha, B. and Belagali, S.L. 2007. Diversity indices of rotifers for the assessment of pollution in the lakes of Mysore city. India. Poll. Res., 26(1): 65-68.

Petersen, C.G.J., 1913. Valuation of the Sea. II. The animal communities of the sea 
bottom and their importance for marine zoogeography. Rep. Danish. Bioi. Sta.,21: 1- 44.

Pielou, E.C. 1966. The measurement of diversity in different types of biological collections. J. Theor. Bio., 13: 131-144.

Ramakrishna and Dey, A. 2007. Hand book on Indian freshwater molluscs. Zoological Survey of India, Kolkata.

Ray, P. and Ghosh, B.B. 1976. Some ecological considerations of the Hooghly estuary polluted by domestic and industrial wastes under tropical environment. ACMRR/IABO Expert Consultation on Bioassays with Aquatic Organisms in relation to pollution problems, Dubranik, Yugoslavia, 16-19 November, 1976. PI: ACMR/BE/8, 29 September.

Robert. and Ayers, S. 1977. Quality of water for irrigation and drainages. J Irrig drain eng dev., 103(2): 125-154

Rosenberg, D.M. and Resh, V.H. In Freshwater Biomonitoring and Benthic Macroinvertebrate, Chapman and Hall, New York.

Sakhare, S.S. and Kamble, N.A. 2015. Diversified distribution of malacofauna from Hiranyakeshi riverA contemporary study. Int. J. Pure App. Biosci., 3(5): 128-142.

Shanmugan, A., Vairmani, S. 2009. Molluscs in Mangrove: A case Study, In Training Course on Mangrove and Biodiversity., Pp 371-382.

Shannon, C.E. and Wiener, W. 1963. The mathematical theory of communications, University of Illinois
Press, Urbana. Illionis

Sharma, K., Bharadwaj, S.M., Chaturvedi, R.. and Sharma, K.P. 2005. Applicability of diversity indices for a comparative assessment of degree of pollution in lentic and lotic ecosystems and describing vegetation characteristics. Nat. Env and Poll. Tech., 4(1): 101106.

Sharma, K.D., Lal, N. and Pathak, P.D. 1981. Water quality of sewage drains entering Yamuna at Agra. Indian J. Environ. Hlfh., 23: 118 - 122.

Ter, Braak., C.J.F. 1995. Non-linear methods for multivariate statistical calibration and their use in palaeoecology: a comparison of inverse (k-nearest neighbours, partial least squares and weighted averaging partial least squares) and classical approaches. Chemometr Intell Lab Syst., 28: 165180

Ustaoğlu, M.R., Balık, S. and Özbek, M. 2001. Işıklı Gölü (Çivril-Denizli)'nün Mollusca Faunasi. E.U. Journal of Fisheries and Aquatic Sciences., 18: 135-139.

Welch, P. S. 1952. Lilnnology.Mc Grew Hill book Co., New York. Total pages:538

Whittaker, R.H. 1975. Communities and Ecosystems.2nd edn. MacMillan, New York.

Yan, H., Cousins, I.T., Zhang C. and Zhou, Q. 2015. Perfluoroalkyl acids in municipal landfill leachates from China: Occurrence, fate during leachate treatment and potential impact on groundwater. Sci. Total Environ., 524-525: 23-31.

\section{How to cite this article:}

Bhuban Mohan Majhi, Ashim Kumar Nath, Chiranjeeb Dey, Ayan Mondal and Nimai Chandra Saha. 2018. Ecological Assessment of Hooghly - Bhagirathi River System through the Study of Diversity of Bivalves and Gastropods in Relation to Physico-chemical Parameters Int.J.Curr.Microbiol.App.Sci. 7(07): 2700-2715. doi: https://doi.org/10.20546/ijcmas.2018.707.317 